\author{
Master's Student of Balatsky Academic and Scientific Institute of Finance, Economics and Management,

\section{INNOVATIVE APPROACHES IN MARKETING STUDIES OF INDUSTRIAL AND TECHNOLOGY PRODUCTION1}

Aleksandr Teletov Doctor of Economics, Professor, Professor of the Department of Marketing and MIA,

Sumy State University (Sumy, Ukraine);

levgenyi Nagornyi,

Candidate of Economic Sciences, Associate Professor of the Department of Marketing and MIA,

Sumy State University (Sumy, Ukraine);

Maksym Nikonets, Sumy State University (Sumy, Ukraine)

It was considered the complex of market researches of the industrial enterprise, including: the formulation of research objectives in accordance with the existing problem, foundation of method of obtaining data selection, analysis of features of collecting information for industrial and technology products, processing of results and the development of management actions. Complex of researches relates to the development and production, the study of consumer behavior, intermediaries, suppliers and other contractors of the industrial enterprise. It was conducted the analysis of micro- and macroenvironment of marketing and assessment of the competitiveness of one of the basic products for the success of industrial products producer in the market on the example of the concern «Nicmas».

Keywords: marketing researches, industrial marketing, b-to-b marketing, B2B marketing, engineering, industrial and technical production, marketing innovations, marketing of innovations.

DOI: 10.21272/mmi.2017.2-05

Problem statement. The output of industrial and technology products is one of the structural elements of the economy of the country, thus it is essential to ensure its economic security, political independence and improving welfare of the population. Engineering is a leading industry for the production of industrial and technical goods in Ukraine, because it provides other industries with tools, bto-b (B2B) products, is the most active factor in scientific and technological progress and expanded or the same size reproduction of production in general. For this it is necessary to constantly conduct market researches that today are held at many industrial enterprises irregularly, non-systematically or are not carried out at all.

Marketing categories that emerged immediately from the beginning of its existence and is constantly supplemented with new methods [1] according to its development as a science. To the greater or another degree market researches of industrial goods are recreated in the works of famous foreign researchers, such as G. Armstrong, P. Kotler [2], G. Bahyev, V. Tarasevych [3], M. Bikers, Cr. West [4], E. Golubkov [1], F. Webster [5], P. Hag [6], H. Churchill [7] and domestic scientists: B. Danylyshyn [8], M. Belyavtseva, V. Nykolaichuk [9], V. Zozuliov [10], B. Pylypchuk [11], A. Starostina [12], A. Fedorchenko [13] and many other scientists. The need for market research is related to the active emergence of new technologies, informatization of enterprises and the evolution of marketing as a tool of business activities. Despite the fact that over the quarter of the century Ukraine has possessed marketing science, conducting of relevant research and usage of their results have not reached the defining level yet. This especially concerns the

\footnotetext{
1 The paper was written according to budget money from the Ministry of Education and Science in Ukraine, given to develop research topic № SR 0115 U000687 "Fundamentals of development management of innovation culture of industrial enterprises".
} 
О.С. Тєлєтов, Є.І. Нагорний, М.О. Никонець. Інноваційні підходи в маркетингових дослідженнях виробничотехнічної продукції

companies that produce industrial and technical products where market researches are often carried out non-systematically, fragmentically, and their results are not always guiding for making management decisions. Therefore, conducting of complex market researches on industrial goods as well as all appropriate their production and use of contractors, and monitoring of marketing micro- and macroenvironments are actual.

The purpose of the article is to develop common innovative approaches to industrial enterprises that produce goods for industrial and technical purposes, complex market researches and effective use of their results.

Basic material. Industry, that is the main systemically important element of the state scope of activity: economic, budgetary, scientific and educational, social, tax, financial and other, in Ukraine has extensive socio-economic, organizational, technological, territorial structure. Industry integrates achievements of scientific and technological progress (STP), and is the basis for transformations at the macro and regional levels and is an indicator of the economic potential of any country [14].

In the market environment industry is covered by the category of b-to-b marketing, table 1 , which schematically shows the classification system of concepts of $b$-to-b marketing, industrial marketing and marketing of industrial and technical products. The definition of marketing of industrial and technical products is as follows: a system of measures aimed at customer satisfaction and consists of obtaining relevant marketing information, creation of technical products that are used for the development, production of other goods, research and services, as well as pricing policy, promotion and distribution of goods.

Table 1 - Place of marketing of industrial and technical products of b-to-b marketing

\begin{tabular}{|c|c|c|c|c|c|c|c|}
\hline \multicolumn{8}{|c|}{ "BUSINESS TO BUSINESS" MARKETING } \\
\hline \multirow{4}{*}{$\begin{array}{l}\text { Products of } \\
\text { intellectual } \\
\text { work in the } \\
\text { sphere of } \\
\text { new } \\
\text { products } \\
\text { creating }\end{array}$} & \multirow{4}{*}{$\begin{array}{l}\text { Educational, } \\
\text { business and } \\
\text { consultative } \\
\text { services that } \\
\text { allow to do } \\
\text { business }\end{array}$} & \multicolumn{6}{|c|}{ INDUSTRIAL MARKETING } \\
\hline & & \multirow[b]{3}{*}{$\begin{array}{l}\text { Technical } \\
\text { services }\end{array}$} & \multirow{3}{*}{$\begin{array}{l}\text { Objects of } \\
\text { capital } \\
\text { construction: } \\
\text { buildings, } \\
\text { structures, } \\
\text { transmitters }\end{array}$} & \multicolumn{4}{|c|}{ MARKETING OF INDUSTRIAL AND TECHNICAL PRODUCTS } \\
\hline & & & & \multirow{2}{*}{$\begin{array}{l}\text { Materials, raw } \\
\text { materials, } \\
\text { semi-finished } \\
\text { products, } \\
\text { components, } \\
\text { energy }\end{array}$} & \multicolumn{3}{|c|}{\begin{tabular}{|c|} 
MARKETING \\
INDUSTRIAL PRODUCTION DESIGN
\end{tabular}} \\
\hline & & & & & $\begin{array}{l}\text { Machinery, } \\
\text { equipment, } \\
\text { vehicles, tools, } \\
\text { instruments } \\
\text { and inventory }\end{array}$ & $\begin{array}{l}\text { High- } \\
\text { technology } \\
\text { products, } \\
\text { laboratory } \\
\text { equipment }\end{array}$ & $\begin{array}{l}\text { High technology } \\
\text { products, } \\
\text { products of } \\
\text { individual } \\
\text { production }\end{array}$ \\
\hline \multirow{3}{*}{$\begin{array}{l}\text { Innovative } \\
\text { scientific } \\
\text { and } \\
\text { technical } \\
\text { ideas }\end{array}$} & \multirow{3}{*}{\multicolumn{2}{|c|}{ Service sector }} & Infrastructure & $\begin{array}{c}\text { The basis for } \\
\text { the future } \\
\text { production }\end{array}$ & \multicolumn{3}{|c|}{ Production of capital goods } \\
\hline & & & \multicolumn{2}{|c|}{ Something, that helps } & \multicolumn{3}{|c|}{ Something, that is produced directly } \\
\hline & & & \multicolumn{5}{|c|}{ PRODUCTION } \\
\hline
\end{tabular}

Industry structure of engineering is very diverse. Until recently the most developed in Ukraine were heavy, transport and agricultural machinery, machine tools, instrumentation, automotive, consumer manufacturing, production of electrical and electronic equipment. In summary, engineering is divided into heavy, general, average and precision [8]: a) heavy machinery is a set of industries that emit large and metal-machinery, equipment for the power industry, metallurgy, mining and chemical industries; b) general machinery includes production of equipment for oil and chemical industry, production of building, road, transport and agricultural machines; c) average mechanical engineering specializes in the manufacture of transport equipment for light industry, food, feed milling and printing industry; d) accurate and high-tech engineering produces electronic, radio, computer and aerospace technics and others.

As of 2016 in Ukraine there were 54,5 thousand of industrial enterprises, 37,6 thousand of which were small ones, 3530,8 thousand people work there, or one fifth of the total employed population, and 
they produce goods and services for more than 70 sub-industries. Industrial output of the country provides more than one third of total GDP, almost $50 \%$ of goods and services and also $80 \%$ of exports [15]. In 2015 production volumes at mechanical engineering enterprises, compared to the previous year, has decreased significantly and the overall dynamics of certain products is shown in the table 2 .

Table 2 - Dynamics of production of some industrial and technically complicated products in Ukraine for the last 30 years

\begin{tabular}{|l|c|c|c|c|c|c|c|}
\hline Name of product groups, thousand pcs. & \multicolumn{7}{|c|}{ The period of observation in years } \\
\cline { 2 - 9 } & 1985 & 1990 & 1995 & 2000 & 2005 & 2010 & $2015^{*}$ \\
\hline Equipment for building and road construction & 16,5 & 18,4 & 4,2 & 1,3 & 4 & 7,7 & 4 \\
\hline Home appliances & 4182 & 5465 & 1090 & 638 & 1215 & 977 & 680 \\
\hline Agricultural machinery & 529 & 430 & 39 & 15 & 27 & 16 & 9 \\
\hline Road transport & 213 & 196 & 67 & 32 & 211 & 287 & 55 \\
\hline
\end{tabular}

*Note: It is given an estimated data for 2015

Negative dynamics of the table confirms the current state of enterprises producing industrial and technical products in Ukraine, namely: obsolete fixed assets, insufficient pay, limited domestic demand for domestic products; low innovation activity, dependence on the deliveries of details and components from other countries; ineffective government policy regarding the activities of monopolists, suppliers of the raw material and intermediaries, which leads to increased cost of materials, energy and so on.

As an exemplar of the object of scientific research it was taken founded in 1994 concern «Nicmas», based on VNDIKOMPRESORMASH, specializing in the production of compressor equipment, creation of information technologies, trade, freight transport, printing services, residential and industrial construction [16], that are already certified in the quality management system ISO 9001: 2008 [17]. Economic activity of the concern «Nicmas» includes the following components. Engineering. In TOV "MIKEM" it is concentrated scientific and intellectual potential of the concern, its main task is the development and production of new high technologies and equipment, implementation of mutually beneficial, effective forms of scientific and industrial cooperation of experts from different countries, sectors, departments, research schools, cultures and technologies [18, 19]. Compressor equipment. Development and production of modern high-efficiency and energy-saving compressor equipment, which is realized on the innovative and engineering base, as well as modernization and technical re-equipment of energy facilities [20]. Power equipment. Production of power equipment includes manufacture and repair of details and components of turbines, feed pumps, turbo blast-engines and modernization of turbine equipment [21]. Foundry engineering. JSC "Poltava Turbomechanical Plant" specializes in the production of compressor equipment, details and components for the repair and reconstruction of steam turbines, welding and pumping units and production of foundry engineering [22, 23]. Service and repair parts (service centers). It provides full support of produced vehicles during the subsequent operation, performing a wide range of services [24].

According to $[10,12,13]$ planning of marketing researches involves passing the following steps: existing problem, determining of research objectives, identification of research tasks, making a plan of the research, data collection, their processing, determining the value of the information, making recommendations. Let us specify the sequence according to marketing of industrial and technical products [14].

The existing problem. The industrial market has a specific character, because there work highly specialized experts in narrow fields of activity. That is why the producers seek to thoroughly conduct market researches as on manufactured goods and all contractors of relevant target market, and explore marketing micro- and macroenvironment that is not always appropriate for b-to-c goods (consumer 
О.С. Тєлєтов, Є.І. Нагорний, М.О. Никонець. Інноваційні підходи в маркетингових дослідженнях виробничотехнічної продукції

goods). Determining of research objectives. Successful performance of the enterprise on the market requires constant gathering of relevant information, the processing of which can further help to gain competitive advantages, reduce financial risk, change consumer responses concerning products of the company, correct industrial strategy of the enterprise, improve the efficiency of marketing services and others. Identification of research tasks. Development of search questions, hypotheses of responses, defining the research boundaries of the marketing micro- and macroenvironment of the enterprise, competitors, suppliers of raw materials, intermediaries and consumers of engineering goods should be carried out by experts, appropriate systems of artificial intelligence [14] and so on. Making a plan of the research. Market researches in the field of industrial products have their own characteristics, because the general totality may vary depending on the specifics and seriality of products produced by the enterprise, its size, the number of contractors etc. [3, 4, 5, 7]. Evaluation of competitiveness of the enterprise and analysis of macro environment (natural, scientific and technical, economic, political, demographic, environmental factors) is carried out mainly through desk research and the quality, technical level of manufactured products and analysis of micro environment - by means of information from management, developers, specialists from different business units and individual producers. For conducting researches in the field of industrial and technical products there is a wide range of methods for getting marketing data, but the most appropriate of them are questionnaires, personal surveys, laboratory experiment and exhibition activity with the demonstration of the prototype. Directions of organization of gathering the necessary marketing information contain, as a rule, survey of products manufacturers, suppliers of raw materials, intermediaries, consumers, manufacturers and also persons who are able to evaluate both the quality and technical level of similar products and the competitiveness of their manufacturers.

Let us more detailed consider the proposed complex on the example of the concern «Nicmas», as of the 1 st of January, 2017 the number of employees is 1419 persons. Representative sample includes developers, manufacturers, managers of product distribution services group and the final consumers, intermediaries (including dealers), raw material suppliers, representatives of partner companies. Desk research conducted concerning micro and macro marketing environment of the company.

Analysis of macroenvironment of the concern. Ukraine has sufficient resource base for its normal functioning. Climatic features are positive. The foundry plant has necessary cleaning system. High level of knowledge intensity for development and implementation of new technologies. Rise in price of energy, devaluation of national currency, inflation and conversion for new markets influence the concern. The demographic situation in Ukraine is characterized by declining the birth rate, aging population, significant migration, high unemployment level, but also Ukrainian high educational level.

Analysis of microenvironment of the concern. The main suppliers are 11 Ukrainian enterprises. System of intermediaries are dealers in Ukraine, the Russian Federation, Republic of Kazakhstan and Republic of Uzbekistan. Major competitors are 13 domestic and 5 representatives of foreign manufacturers in Ukraine. External contact group: financial institutions JSC "Raiffeisen Bank Aval" and PJSC "FUIB", representation of the concern in the Internet and mass media, magazine "Compressor and power engineering."

Let us consider the list of investigated respondents of the concern «Nicmas». The main suppliers of the concern are: "Specsplav", "Det-ua", "AL-KO Kober", "Spec Metal", "Mitaltreid", "Dnipro-Carbon", "Vtortsvetmetresurs", "Ecocenter Plus", "Metkor", "Ferrometgroup", "Progress Group". Dealers (intermediaries) of the concern in Ukraine are "Ukrkompressormash Service" in Kyiv, "Orelkompressormash" in the Russian Federation, "Asia Prom Package" and "TehStroySnabPlyuS" in Kazakhstan, "75-Maxsus Boshqarmasi" in Uzbekistan. Competitors of the concern "Nicmas" are domestic Azov engineering plant, "Berdyansk pumps", Belopolskiy engineering plant, "Hydraulic", "Hidrovest", "Grace Engineering", "Energomash", "Enerhomashengineering", "Consortium", Kamyanskyy 
engineering plant, "Energy systems", company "EnergoAir", "Nasosenerhoprom" and representatives of foreign producers in Ukraine: the company "Dalgakiran Compressor Ukraine", "Galkostservis" company "Sigma Engineering"; "STARK Industry", "Compressor technologies". The internal contact audiences include: management, professionals, staff, media (including own press center), scientific centers of regional high educational establishments, local contact audience (families of workers, sport schools and competitions, festivals and artistic contests, etc.) public.

In the complex of marketing researches of the industrial enterprise it is offered to use $\mathbf{n}$ kinds of questionnaires, answers of which are directed to: identify the main difficulties encountered in research and development, the need for procurement of better raw materials or the latest materials, updating of existing and introduction of innovative production technologies; obtain information about the current situation of manufacturer, competitors and possible changes in the target market; obtain information about the possibility of rising prices for raw materials, the need for additional supplies of components or replacement of existing components for alternative (advanced) ones; obtain information about the most important characteristics of the goods to the consumer, changes that should be entered into the composition of the product, the type of pre-sales and after-sales service; to clarify the existing production system and options for making possible changes to it, and to assess the competitiveness of goods in comparison with competing products.

Processing and analysis of the results of the conducted study. According to the opinion of developers and manufacturers of innovative products, the key factors in creating new products are the use of modern equipment and introduction of new principles of manufactured products action: improving of product parameter values, the transition to rational technical solutions and the transition to more rational physical principle of action. The assessment of the importance degree of technical innovations introduction according to the results of the conducted studies is shown in the Table 3.

Table 3 - The assessment of innovative changes necessity according to the scale of importance

\begin{tabular}{|l|c|c|c|c|}
\hline \multirow{2}{*}{\multicolumn{2}{c|}{ Investigated indicators }} & \multicolumn{3}{|c|}{ The degree of the necessity to improve compressor equipment of the } \\
concern «Nicmas», \%
\end{tabular}

The results of general consumer satisfaction by the level of compressor quality and its service and the level of the enterprise-manufacturer with intermediaries and suppliers of materials and raw materials are shown in the Table 4.

Table 4 - The assessment of the quality of work and products

\begin{tabular}{|l|c|c|c|c|}
\hline \multirow{2}{*}{\multicolumn{1}{c}{ Investigated indicators }} & \multicolumn{3}{|c|}{$\begin{array}{c}\text { The degree of satisfaction with quality indicators of compressor } \\
\text { equipment of the concern «Nicmas», in percentage }\end{array}$} \\
\cline { 2 - 5 } & $\begin{array}{c}\text { Completely } \\
\text { satisfied }\end{array}$ & $\begin{array}{c}\text { Generally } \\
\text { satisfied }\end{array}$ & $\begin{array}{c}\text { Partially } \\
\text { satisfied }\end{array}$ & Not satisfied \\
\hline The assessment of service & 37,5 & 37,5 & 25 & - \\
\hline General assessment of compressor's quality & 25 & 62,5 & 12,5 & - \\
\hline The assessment of cooperation with suppliers & 36,6 & 54,4 & 9 & - \\
\hline The assessment of cooperation with intermediaries & 40 & 30 & 30 & - \\
\hline
\end{tabular}

Making management decisions according to the results of conducted complex marketing researches. The combination of innovative solutions mainly adopts in accordance with the classical elements of the marketing complex [2, 9, 11]. Decisions related to the improvement of the element 
О.С. Тєлєтов, Є.І. Нагорний, М.О. Никонець. Інноваційні підходи в маркетингових дослідженнях виробничотехнічної продукції

product, concern the compilation of an appropriate strategy from two directions: improving the technical level of products and improving the quality of work from their creation, both individual employees and the company as a whole. These management measures are developed in accordance with: results of the comparison of technical parameters of the product with the indicators of the best similar world standards, or the so-called perfect product, deviations of values of the parameters of technological processes from creating products according to regulations, compliance eligibility of products with international quality standards of labor and production. Relevant information can be obtained according to the results of desk and field marketing researches and the results of expert assessment in terms of incomplete, unclear and limited data that are collected on the basis of summarizing judgments of highly qualified specialists, using the method of obtaining marketing data as an experiment, and the use of artificial intelligence systems [14]. Processed results make it possible to put the incentives of developers and innovative technology manufacturers in direct dependence from the quality of manufactured products and reduce rejection of labor and technological processes from norms. Table 5 shows the results of evaluation of the competitiveness of compressor VVP 10/10 U1, produced by the concern «Nicmas», and compressors (mobile compressor stations) PV-10/8 M1 ("Servo C") and NV-10E (NPP "Polenerhokompleks").

Table 5-Comparison of technical level of parameters of the compressor VVP 10/10 U1, produced by «Nicmas» and analog products

\begin{tabular}{|l|c|c|c|c|c|}
\hline $\begin{array}{c}\text { The name of the } \\
\text { product }\end{array}$ & $\begin{array}{c}\text { Production of air } \\
\text { pressure, } \mathrm{m}^{3} / \mathrm{min}\end{array}$ & Power, $\mathrm{kW}$ & $\begin{array}{c}\text { Pressure, } \\
\text { bar }\end{array}$ & $\begin{array}{c}\text { Weight } \\
\mathrm{kg}\end{array}$ & $\begin{array}{c}\text { The deviation of value of generalized } \\
\text { quality indicator from ideal }\end{array}$ \\
\hline VVP 10/10 U1 & 10 & $\mathbf{9 0}$ & 10 & $\mathbf{1 5 0 0}$ & $\mathbf{0 . 0 6}$ \\
\hline PV-10/8 M1 & 11 & 74 & 11 & 3080 & 0,17 \\
\hline NV-10E & 10 & 66 & 7 & 1850 & 0,23 \\
\hline
\end{tabular}

That is, although today mobile compressor station VVP 10/10 U1 of the concern «Nicmas» has a tangible advantage over analog products of competing firms, comprehensive studies for early identification of trends in creating and bringing to market new products should be conducted systematically. According to the results of such researches developers will constantly work on improving the quality and technical level of the new models to assure a successful competition in industrial goods market. In this case it is: changes in the composition and structure of used materials and construction; improving the procedure of products designing and manufacturing; introduction of new stands for testing; regulation of prices for products and related services.

According to the results of surveys of producers it was determined that it is necessary to some extent reorganize the production process through the partial modernization of existing equipment. To make this, every head of the department has to report about existing equipment, terms of its usage and generation of a list of priority replacement of its mentally and physically worn-out pieces. On the basis of the survey of intermediaries it was identified the need to increase the percentage of repeat purchases of concern's products. The solution of this problem lies in the implementation of the complex of maintenance and corrective measures, developed according to the results of survey of consumers, and measures that will improve the efficiency of distribution channels, based on the analysis of survey of intermediaries and partners. While the increase in price of materials and raw materials directly affects the business, because the cost of production also increases, it is identified that it is necessary to conduct more detailed examination concerning the increase in price of raw materials or components, in order to have the possibility to generate any early measures to overcome this problem.

Analysis of the factors of marketing micro- and macroenvironment of the business of the concern «Nicmas» enables to soften negative impact of some of them, to lobby interests of the enterprise on the local, national and international levels, taking into account the political situation, install system of filters on environmentally polluting manufacturing places and so on. In general, detailed analysis of raw 
material suppliers, intermediaries, customers, competitors and contact audiences makes it possible to gather information on existing and potential counterparties and consequently take management decisions that form the respective strategic and operational decisions.

Let us list some of them: usage of more efficient engines, implementation of management system based on microprocessors of own production; formation of through working groups involved in the work from the moment of products designing till its sale; change in manufacturing technology, testing methods, quality control system for production, storage, packaging, transportation and installation of manufactured products; development and implementation of new stands for testing and certification of products (IRIS standards and ISO 9001); change in prices of products, services, servicing and repair, and the price of spare parts (setting fixed prices for end customers); using dealer networks and sales via the Internet; improving the structure and scope of cooperation supplies during the production, prices for components, the composition of selected suppliers of raw materials: forming of cooperation in the middle of the concern among the parties; improvement of incentive providers system, (introduction of long-term contracts); changes in the structure of imports (kinds of imported products and the optimization of its number according to the ratio of parameters "price - quality") and import substitution.

Implementation of necessary communicative measures according to the results of marketing researches. In terms of competition and globalization of markets to achieve the expected result (expanding sales, creating a positive market image of the industrial enterprise, etc.) it is used a communication model that forces to withdraw from passive adaptation to market conditions and move to the policy of impact on the market for active creating the demand for products. The basis of the effectiveness of communicative solutions form the following functional components: information, persuasion, creating an image, support, personal experience of customers and their feedback about the product is the main component which is crucial for providing the feedback.

According to the results of complex marketing researches, it is forming a system of communications that can partially overcome problems identified during these researches. Their tools are: participation in specialized exhibitions and fairs, because many contracts are concluded either directly at the exhibition, or a few days after its completion (direct communication with partners at exhibitions and fairs is the shortest way to the development of business communication); advertising in the Internet: constantly improved Internet sites, posting articles on the Internet portals and own website of the concern, where it is posted articles on events or activities conducted by the company; printed advertising that contains the most complete information about the produced products (advantages - focus on specific individuals and specific markets, the possibility of the personal submission until the absolute confidentiality, no restrictions in place, time and format, wide opportunities in the choice of materials and methods of information presentation, control through specific research tasks taking into consideration different groups of indicators to test ideas, motives of reactions, possibility of advertising in strict compliance to the product life cycle, etc.), table 6; public relations - promotion, sponsorship, conferences, interviews, strengthen of contacts with the media, publicity, influential personalities; direct marketing — provides the creation of the most detailed customer base, which displays complete information about ongoing and potential customers from their overall characteristics, ending with data on their personal preferences.

Table 6 - Printed advertising products

\begin{tabular}{|l|l|l|l|l|}
\hline \multicolumn{1}{|c|}{$\begin{array}{c}\text { Name of product } \\
\text { advertising }\end{array}$} & \multicolumn{1}{|c|}{$\begin{array}{c}\text { The quality of } \\
\text { materials }\end{array}$} & \multicolumn{1}{|c|}{ Amount } & \multicolumn{1}{|c|}{ The emphasis } & Stage of the life cycle \\
\hline Information flyer & Inexpensive paper & 1 sheet & General information & Development \\
\hline Novelty prospect & $\begin{array}{l}\text { An average quality, } \\
\text { black and white photos }\end{array}$ & $\begin{array}{l}\text { Brief } \\
\text { information }\end{array}$ & $\begin{array}{l}\text { Benefits to } \\
\text { consumers }\end{array}$ & $\begin{array}{l}\text { The introduction into } \\
\text { the market }\end{array}$ \\
\hline The main prospect & $\begin{array}{l}\text { Coloured photos, the } \\
\text { best printing }\end{array}$ & Full volume & Properties & Growth \\
\hline
\end{tabular}


An important part of the communication policy of the company is to develop internal corporate communications, the specificity of which is the following: on the one hand, for employees its activity is an essential and important part of their own existence and therefore becomes important for them. On the other hand, employees of the company are leaders of this activity; they can see how pronounced values coincide with the real ones. Conclusions about what is "wrong" and at what stage in the company employees have a sense of satisfaction or dissatisfaction with their membership in this group are made. As it is known, favorable and trusting relationships of management with personnel at all levels of the enterprise is one of major factors of its successful development. Stable microclimate of any structure is important, because employees of the enterprise, firm, company, institution are the first who find out about all the news, both positive and negative, and share them with their friends, colleagues and clients. In this case, the lack of awareness of employees can distort the facts about the company that negatively affect its image. Therefore, to prevent the spread of incorrect information it is necessary to create and maintain a single information space and to establish obtaining "feedback" of personnel, which is achieved with the help of integrated marketing research.

Algorithms of domestic corporate relations are corrected after the annual internal research of the enterprise, the so-called communication audit that includes: in-depth interviews, surveys, focus groups, corporate media, the Internet, information stands, meetings with top management, meetings, Code of Corporate Ethics), corporate standards, training on team building, corporate events and promotions, management of rumors.

Conclusions. The market of industrial and technical products is characterized by specific properties, narrow specialized directions of activity and highly qualified specialists. That is why industrial producers have to conduct market researches of both manufactured goods and those relating directly to all counterparties of target market as perfect as possible.

It is confirmed that the complex of marketing research of the industrial enterprise gets appropriate information from: developers of new technology concerning the usage of new raw materials or components for the development of innovative products, availability of modern equipment and information about the process from pre-production to release new or upgrading existing products; suppliers of raw materials concerning possible price fluctuations for raw materials and components, readiness for flexible action in their supply, the possibility of expanding the range of materials for supplies in the medium term and about he long-term cooperation with the manufacturer; consumers of industrial and technical products concerning satisfaction level of service of manufactured products, the possibility of its equipping with additional equipment, evaluation of the quality of the investigated products, the need to make structural changes to the model or the technology of its manufacture, convenience to use products, as well as attitudes to competitors and the analog goods produced by them; intermediaries concerning satisfaction by terms of cooperation with the enterprise, the perception by potential buyers of products its quality characteristics, the ratio of sales of the enterprise's production in comparison with similar products from other manufacturers, the structures of possible exports, the number of customers engaged in repeat purchase of products and possible changes of the market situation for certain period, the structure of selected suppliers, systems of their incentives.

Intercorporate researches of employees are aimed to determine satisfaction with the existing production system of production, the need for changes in the production process, assessment and possible ways to improve the existing system of organization and production and the need for imports of certain types of materials and components. Summarized results of market researches allow to not only produce the necessary managerial influence concerning strategic and tactical actions of the enterprise, but also stimulate enterprise units and individual employees to improve the quality of work.

Further scientific studies are desirable to dedicate to the expansion of methodology for appropriate assessment of results significance of market research and development of reasonable recommendations for their usage and making effective management decisions. 
1. Голубков Е.П. Маркетинговые иследования: теория, методология и практика / Е.П. Голубков. - М. : Издательство «Финпресс», 2003. - 416 с.

2. Армстронг Г. Маркетинг. Загальний курс / Г. Армстронг, Ф. Котлер. - 5-те вид. - М.: Видавничий дім "Вільямс", 2001. -608 c.

3. Багиев Г.Л. Маркетинг / Г.Л. Багиев, В.М. Тарасевич. - 3-е изд. - СПб. : Питер, 2010. - 576 с.

4. Уэст Кр. Маркетинговые исследования. / Кр. Уест // Маркетинг [Энциклопедия : пер. с англ.] Под. ред. М. Бейкера (серия : Бизнес-класс). - СПб. : Питер, 2002. - С. 317-325.

5. Уэбстер Ф. Основы промышленного маркетинга / Фредерик Уэбстер. - М.: Издательский дом Гребенникова, 2005. $-416 c$.

6. Хаг П. Маркетинговые иследования: руководство по планированию, методологии и оценке / П. Хаг. - К.: ЗнаниеПрес, 2005. $-416 \mathrm{c}$

7. Черчилль Г.А. Маркетинговые исследования / Г.А. Черчилль. - СПб. : Питер, 2000. - 752 с.

8. Данилишин Б. Машинобудування відновлює свої позиції / Б. Данилишин // Урядовий кур'єр. - 2009. - №194 - с.4.

9. Николайчук В.Е. Промышленный маркетинг / В.Е. Николайчук, М.И. Белявцев. - Донецк : ООО ПКФ «БАО», 2004. -384 c.

10. Зозульов О.В. Основні етапи розробки анкети в процесі маркетингових досліджень / О.В. Зозульов // Маркетинг в Україні. - 2002. - №5 (15). - С. 34-36.

11. Пилипчук В. П. Маркетингова діяльність промислових підприємств та тенденції її розвитку. Теорія і практика маркетингу в Україні : монографія / А.Ф. Павленко, А.В. Войчак, В.Я. Кардаш, В.П. Пилипчук та ін.; за наук. ред. д-ра екон. наук. проф., акад. АПН України А.Ф. Павленка. - К.: КНЕУ, 2005. - С. 183-212.

12. Старостіна А.О. Маркетингові дослідження. Практичний аспект / А.О. Старостіна // К.; М.; СПб. : Видавничий дім "Вільямс", 1998. - 262 с.

13. Федорченко А. В. Маркетингові дослідження в системі управління промисловим підприємством. Теорія і практика маркетингу в Україні : монографрія / А.Ф. Павленко, А.В. Войчак, В.Я. Кардаш, В.П. Пилипчук та ін.; за наук. ред. д-ра екон. наук. проф., акад. АПН України А.Ф. Павленка. - К.: КНЕУ, 2005. - С. 340-356.

14. Тєлєтов О.С. Маркетинг продукції виробничо-технічного призначення : монографія / О.С. Тєлєтов - Суми : Вид-во СумДУ, 2002. -231 с

15. Сучасний стан і перспективи розвитку промисловості України [Електронний ресурс]. - Режим доступу: http://lib.chdu.edu.ua/pdf/monograf/47/10.pdf.

16. О Концерне [Електронний ресурс]. - Режим доступу: http://nicmas-market.com/content/2517.

17. О направлениях [Електронний ресурс]. - Режим доступу: http://nicmas-market.com/ compressor-urm/2605

18. Инжиниринг [Електронний ресурс]. - Режим доступу: http://nicmas-market.com/engineering-urm/2528.

19. О КОМПАНИИ ООО «МИКЭМ» [Електронний ресурс]. - Режим доступу: http://mikem.com.ua/o kompanii.html.

20. Компрессорная техника [Електронний ресурс]. - Режим доступу: http://nicmas-market.com/ compressor-urm/2604.

21. Энергетическое оборудование[Електронний ресурс]. - Режим доступу: http://nicmasmarket.com/ energy-urm/2571

22. АО «Полтавский турбомеханический завод» - лидер машиностроения Украины [Електронний ресурс]. - Режим доступу: http://old.ptmz.com.ual.

23. Ливарне виробництво [Електронний ресурс]. - Режим доступу: http://nicmas-market.com/ foundry-urm/2581.

24. Сервіс та запчастини [Електронний ресурс]. - Режим доступу: http://nicmas-market.com/ service-urm/2576.

1. Holubkov, E.P. (2003). Marketinhovye issledovaniia: teoriia, metodolohiia i praktika [Marketing research: theory, methodology and practice]. Moscow: Izdatelstvo «Finpress» [in Russian].

2. Armstronh, H., \& Kotler, F. (2001). Marketynh. Zahalnyi kurs [Marketing. General course]. Moscow: Vydavnychyi dim «Viliams» [in Russian].

3. Bahiev, H.L., \& Tarasevich, V.M. (2010). Marketinh [Marketing]. Saint Petersburg: Piter [in Russian].

4. Uest, Kr. (2002). Marketinhovye issledovaniia [Marketing research]. Saint Petersburg: Piter [in Russian].

5. Uebster, F. (2005). Osnovy promyshlennoho marketinha [Basics of industrial marketing]. Moscow: Izdatelskii dom Hrebennikova [in Russian].

6. Khah, P. (2005). Marketinhovye issledovaniia: rukovodstvo po planirovaniiu, metodolohii i otsenke [Marketing research: a guide to planning, methodology and evaluation]. Kyiv: Znanie [in Russian].

7. Cherchill, H.A. (2000). Marketinhovye issledovaniia [Marketing research]. Saint Petersburg: Piter [in Russian].

8. Danylyshyn, B. (2009). Mashynobuduvannia vidnovliuie svoi pozytsii [Mechanical engineering restores its position] Uriadovyi kurier - Governmental courier, 194, 4 [in Ukrainian].

9. Nikolaichuk, B.E., \& Beliavtsev, M.I. (2004). Promyshlennyi marketinh [Industrial marketing]. Donetsk: OOO PKF «BAO» [in Russian].

10. Zozulov, O.V. (2002). Osnovni etapy rozrobky ankety v protsesi marketynhovykh doslidzhen [The main stages of the questionnaire in the marketing research]. Marketynh v Ukraini - Marketing in Ukraine, 5 (15), 34-36 [in Ukrainian].

11. Pylypchuk, V.P. (2005). Marketynhova diialnist promyslovykh pidpryiemstv ta tendentsii ii rozvytku [Marketing activities of industry and its development trends]. Teoriia i praktyka marketynhu v Ukraini - Theory and practice of marketing in Ukraine, (pp. 183-212). Kyiv: KNEU [in Ukrainian]. 
О.С. Тєлєтов, Є.І. Нагорний, М.О. Никонець. Інноваційні підходи в маркетингових дослідженнях виробничотехнічної продукції

12. Starostina, A.O. (1998). Marketynhovi doslidzhennia. Praktychnyi aspekt [Marketing researches. Practical aspects]. Moscow, Saint Petersburg [in Ukrainian].

13. Fedorchenko, A.V. (2005). Marketynhovi doslidzhennia v systemi upravlinnia promyslovym pidpryiemstvom [Market research in the management of industrial enterprise]. Teoriia i praktyka marketynhu $v$ Ukraini - Theory and practice of marketing in Ukraine, (pp. 340-356). Kyiv: KNEU [in Ukrainian].

14. Tielietov, O.S. (2002). Marketynh produktsii vyrobnycho-tekhnichnoho pryznachennia [Marketing of products for industrial purposes]. Sumy: Vyd-vo SumDU [in Ukrainian].

15. Suchasnyi stan i perspektyvy rozvytku promyslovosti Ukrainy [The current state and prospects of the industry in Ukraine]. (n.d.). lib.chdu.edu.ua. Retrieved from http://lib.chdu.edu.ua/pdf/monograf/47/10.pdf [in Ukrainian].

16. O Kontserne (n.d.). nicmas-market.com. Retrieved from http://nicmas-market.com/content/2517 [in Russian].

17. O napravleniiakh [On directions]. (n.d.). nicmas-market.com. Retrieved from http://nicmas-market.com/ compressorurm/2605 [in Russian]

18. Inzhinirinkh [Engineering]. (n.d.). nicmas-market.com. Retrieved from http://nicmas-market.com/engineering-urm/2528 [in Russian].

19. O kompanii 000 «MIKEM» [About the company «MIKEM»]. (n.d.). mikem.com.ua. Retrieved from http://mikem.com.ua/o_kompanii.html [in Russian].

20. Kompressornaia tekhnika [Compressor equipment]. (n.d.). nicmas-market.com. Retrieved from http://nicmas-market.com/ compressor-urm/2604 [in Russian].

21. Enerheticheskoe oborudovanie [Power equipment]. (n.d.). nicmas-market.com. Retrieved from http://nicmasmarket.com/energy-urm/2571 [in Russian].

22. AO «Poltavskii turbomekhanicheskii zavod» - lider mashynostroeniia Ukrainy [JSC «Poltava Turbomechanical Plant» the leader of mechanical engineering of Ukraine]. (n.d.). old.ptmz.com.ua. Retrieved from http://old.ptmz.com.ua/ [in Russian].

23. Lyvarne vyrobnytstvo [Foundry production]. (n.d.). nicmas-market.com. Retrieved from http://nicmas-market.com/ foundry-urm/2581 [in Ukrainian].

24. Servis ta zapchastyny [Service and parts]. (n.d.). nicmas-market.com. Retrieved from http://nicmas-market.com/ serviceurm/2576 [in Ukrainian].

О.C. Тєлєтов, д-р екон. наук, професор, професор кафедри маркетингу та УІД, Сумський державний університет (м. Суми, Україна);

Є.І. Нагорний, канд. екон. наук, доцент кафедри маркетингу та УІД, Сумський державний університет (м. Суми, Україна);

M.О. Никонець, магістрант НH ффінансів, економіки і менеджменту імені Олега Балацького, Сумський державний університет (м. Суми, Україна)

Інноваційні підходи в маркетингових дослідженнях виробничо-технічної продукції

Розалянуто комплекс маркетингових досліджень промислового підприємства, що містить: формулювання иілей дослідження, відповідно до існуючої проблеми, обгрунтування вибору методу отримання даних, аналіз особливостей збирання інформації для виробничо-технічної продукції, обробку результатів та вироблення управлінських впливів. Комплекс досліджень стосується розроблення та виробництва продукції, вивчення поведінки споживачів, посередників, постачальників сировини та інших контрагентів промислового підприємства. Проведено аналіз маркетингового мікроі макросередовища та оцінку конкурентоспроможності одного з базових видів продукиії для забезпечення успіху виробника на ринку промислових товарів на прикладі концерну «Nicmas».

Ключові слова: маркетингові дослідження, промисловий маркетинг, b-to-b маркетинг, В2B маркетинг, машинобудування, виробничо-технічна продукція, інновації в маркетингу, маркетинг інновацій.

A.C. Тєлєтов, д-р экон. наук, профессор, профессор кафедры маркетинга и УИД, Сумский государственный университет (г. Сумы, Украина):

Е.И. Нагорный, канд. экон. наук, доцент кафедры маркетинга и УИД, Сумский государственный университет (г. Сумы, Украина);

М.A. Никонец, студент УНИ финансов, экономики и менеджмента имени Олега Балацкого, Сумский государственный университет (г. Сумы, Украина)

Инновационные подходы в маркетинговых исследованиях производственно-технической продукции

Рассмотрен комплекс маркетинговых исследований промышленного предприятия, который содержит: формирование целей исследования в соответствии с существующей проблемой, обоснование выбора метода получения данньх, анализ особенностей сбора инсрормации для производственно-технической продукции, обработку результатов и выработку управляющих воздействий. Комплекс исследований касается разработки и производства продукции, изучения поведения потребителей, посредников, поставщиков сырья и других контрагентов промьшленного предприятия. Проведены анализ маркетинговой микро- и макросреды и оценка конкурентоспособности одного из базовых видов продукции для обеспечения успеха производителя на рынке промышленных товаров на примере концерна «Nicmas».

Ключевые слова: маркетинговые исследования, промышленный маркетинг, b-to-b маркетинг, В2В маркетинг, машиностроение, производственно-техническая продукция, инновации в маркетинге, маркетинг инноваций.

Отримано 25.12.2016 p. 